\title{
HUBUNGAN PENGGUNAAN CLINICAL PATHWAY TERHADAP TINDAKAN LAPARASKOPI DAN LAPARATOMI PADA KASUS MIOMA UTERI DI RSPAD GATOT SOEBROTOBULAN JANUARI-JUNI 2017
}

\author{
Leni Suhartini' ${ }^{1}$, Gunawan Dwi Prayitno ${ }^{2}$ \\ ${ }^{1}$ Akbid RSPAD Gatot Soebroto, Email: leni 2022@yahoo.com \\ 2 Departemen Obstetri dan Ginekologi RSPAD Gatot Soebroto, \\ Email :gunawan_spog04@yahoo.com
}

\begin{abstract}
ABSTRAK
Clinical pathway menyediakan standar pelayanan minimal dan memastikan bahwa pelayanan tersebut tidak terlupakan dan dilaksanakan tepat waktu.Mioma uteri menjadi salah satu pilihan kasus yang diteliti kesesuaian diagnosisnya dengan clinical pathway. Hal ini disebabkan karena kasus mioma uteri sering terjadi dan memerlukan high cost serta hight risk bagi pasien yang menderita kasus tersebut. Penyebab utama mioma uteri belum diketahui secara pasti sampai saat ini, tetapi penyelidikan telah dijalankan untuk memahami keterlibatan faktor hormonal, faktor genetik, growth factor, dan biologi molekular untuk tumor jinak ini.

Metoda penelitian menggunakan Cross sectional. Tujuan penelitian ini untuk mengamati penggunaan clinical pathway terhadap tindakan laparaskopi dan laparatomi atas indikasi mioma uteri berdasarkan variabel lama operasi, jumlah perdarahan saat operasi, komplikasi, lama dirawat (Length Of Stay) dan transfusi pasca operasi.Waktu penelitian dilaksanakan pada bulan Januari sampai Juni2017.Populasi pada penelitian ini adalah seluruh wanita dengan diagnosa mioma uteri yang menjalani operasi baik laparatomi maupun laparoskopi di RSPAD Gatot Soebroto yaitu sebanyak 53 pasien.

Hasil penelitian ini diperoleh 53 kasus mioma uteri, terdapat 21 pasien (39.6\%) laparoskopi miomektomi, 6 pasien (11.3\%) laparoskopi histerektomi, 14 pasien (26.4\%) laparatomi miomektomi dan 12 pasien (22.6\%) laparatomi histerektomi. Penggunaan clinical pathway terhadap kesesuaian diagnosa pre operasi dan pasca operasi 12 kasus (22.6\%) tidak sesuai dan 41 kasus $(77.4 \%)$ yang sesuai. Dari 5 variabel yang diambi (lama operasi, jumlah perdarahan, lenght of stay, komplikasi dan transfusi) hanya ada 1 variabel yang berhubungan dengan penggunaan clinical pathway terhadap tindakan laparatomi dan laparaskopi pada kasus mioma uteri yaitu jumlah perdarahan $(\mathrm{p}=0.036)$.
\end{abstract}

Kata kunci : laparaskopi, laparatomi, mioma uteri, clinical pathway

\begin{abstract}
Clinical pathway provides a minimum service standard and ensures that the service is not forgotten and executed on time. The uterine myoma becomes one of the selected cases in which the diagnosis is determined by clinical pathway. This is because cases of uterine myomas often occur and require high cost and hight risk for patients suffering from the case. The main cause of uterine myoma is not known until now, but investigations have been undertaken to understand the involvement of hormonal factors, genetic factors, growth factors, and molecular biology for these benign tumors.
\end{abstract}


The research method used Cross sectional. The objectives of this study were to observe the use of clinical pathways against laparoscopic and laparotomy measures on the indication of uterine myoma based on long-duration surgery, number of bleeding during surgery, complication, duration of care and postoperative transfusion. The study was conducted in January to June 2017. The population in this study were all women with diagnoses of uterine myoma who underwent laparoscopic or laparoscopic surgery at RSPAD Gatot Soebroto that was 53 patients.

The results of this study obtained 53 cases of uterine myoma, there were 21 patients (39.6\%) laparoscopic myomektomi, 6 patients (11.3\%) d laparoscopic hysterectomy, 14 patients (26.4\%) laparatomi miomektomi and 12 patients (22.6\%) laparatomi hysterektomi. The use of clinical pathways on the suitability of preoperative and postoperative diagnosis of 12 cases (22.6\%) was inappropriate and 41 cases (77.4\%) were appropriate. Of the 5 variables taken (duration of surgery, number of bleeding, lenght of stay, complication and transfusion) there was only 1 variable related to clinical pathway use to laparotomy and laparoscopy in case of uterine myoma $(p=0.036)$.

Keywords: laparoscopy, laparatomy, uterine myoma, clinical pathway

\section{PENDAHULUAN}

Clinical pathway adalah alur yang menunjukkan secara detail tahap-tahap penting dari pelayanan kesehatan termasuk hasil yang diharapkan. Secara sederhana dapat dibilang bahwa clinical pathway adalah sebuah alur yang menggambarkan proses mulai saat penerimaan pasien hingga pemulangan pasien. Clinical pathway menyediakan standar pelayanan minimal dan memastikan bahwa pelayanan tersebut tidak terlupakan dan dilaksanakan tepat waktu. Clinical pathway memiliki banyak nama lain seperti: Critical care pathway, Integrated care pathway, Coordinated care pathway, Caremaps, atauAnticipated recovery pathway. ${ }^{1}$

Hasil analisis digunakan untuk: mengidentifikasi variasi umum dalam pelayanan, memberi sinyal kepada staf akan adanya pasien yang tidak mencapai perkembangan yang diharapkan, memperbaiki clinical pathway dengan menyetujui perubahan dan mengidentifikasi aspek-aspek yang dapat diteliti lebih lanjut. Hasil analisis variasi dapat menetapkan jenis variasi yang dapat dicegah dan yang tidak dapat dicegah untuk kemudian menetapkan solusi bagi variasi yang dapat dicegah (variasi yang tidak dapat dicegah dapat berasal dari penyakit penyerta yang menyebabkan pelayanan menjadi kompleks bagi seorang individu). ${ }^{1}$ Clinical Pathways bisa digunakan sebagai salah satu alat mekanisme evaluasi penilaian risiko penilaian risiko untuk mendeteksi kesalahan aktif (active errors) dan laten (latent / system errors) maupun nyaris terjadi (near miss) dalam Manajemen Risiko Klinis (Clinical Risk Management) dalam rangka menjaga dan meningkatkan keamanan dan keselamatan pasien (patient safety). ${ }^{2}$

Mioma uteri menjadi salah satu pilihan kasus yang diteliti kesesuain diagnosisnya dengan clinical pathway. Hal ini disebabkan karena kasus mioma uteri sering terjadi dan memerlukan high cost serta hight risk bagi pasien yang menderita kasus tersebut. Penyebab utama mioma uteri belum diketahui secara pasti sampai saat ini, tetapi penyelidikan telah dijalankan untuk memahami keterlibatan faktor hormonal, faktor genetik, growth factor, dan biologi molekular untuk tumor jinak ini ${ }^{3}$. Faktor yang diduga berperan untuk inisiasi pada perubahan genetik pada mioma uteri adalah abnormalitas intrinsik pada miometrium, peningkatan reseptor estrogen secara kongenital pada miometrium, perubahan hormonal, atau respon kepada kecederaan iskemik ketika haid. Setelah terjadinya mioma uteri, perubahan-perubahan genetik ini akan 
dipengaruhi oleh promoter (hormon) dan efektor (growth factors) ${ }^{3}$

Mioma uteri yang berasal dari sel otot polos miometrium, menurut teori onkogenik maka patogenesa mioma uteri dibagi menjadi 2 faktor yaitu inisiator dan promotor.Faktor-faktor yang menginisiasi pertumbuhan mioma masih belum diketahui pasti.Dari penelitian menggunakanglucose-6-

phosphatasedihydrogenase iketahui bahwa mioma berasal dari jaringan uniseluler.Transformasi neoplastik dari miometrium menjadi mioma melibatkan mutasi somatik dari miometrium normal dan interaksi kompleks dari hormon steroid seks dan growth factor lokal. Mutasi somatik ini merupakan peristiwa awal dalam proses pertumbuhan tumor. ${ }^{4}$ Sejak histerektomi laparoskopi pertama dilakukan oleh Reich et al. pada tahun 1989, histerektomi laparoskopi telah dianggap metode bedah yang semakin penting dalam mengobati penyakit ginekologi.Teknologi canggih dan teknik laparoskopi telah memungkinkan ahli bedah untuk melakukan operasi secara endoskopi yang sebelumnya diperlukan tindakan laparotomi.Teknik-teknik laparoskopi telah dilaporkan sebagai alternatif untuk histerektomi perabdominal.Bedah invasif yang minimal ini dirintis pada awal 1990 untuk digunakan dalam keganasan ginekologi tetapi juga memiliki sisi kontroversial.Ginekologi onkologi khawatir tentang mengadopsi laparoskopi untuk pengelolaan karsinoma endometrium karena kekhawatiran mengenai waktu operasi yang meningkat, keterbatasan untuk mengangkat kelenjar getah bening dan peningkatan komplikasi.

Studi retrospektif telah menunjukkan sejumlah keuntungan dari histrektomi laparoskopi, termasuk mengurangi masa rawatan, mengurangi rasa sakit dan kebutuhan analgesik paska bedah dan pemulihan aktivitas yang lebih singkat.Perhatian juga telah ditujukan tentang dampak dari laparoskopi pada pola rekurensi dan kelangsungan hidup.Histerektomi laparoskopi diindikasikan pada kondisi tertentu seperti aksesibilitas vagina yang kurang baik, koeksistensi adneksa patologi, endometriosis dan adhesi panggul.Dengan meningkatnya penggunaan dan aplikasi yang lebih luas dari laparoskopi, seperti teknik bedah, risiko komplikasi dalam bedah laparoskopi.Namun, resiko komplikasi pada laparoskopi tidak lebih besar daripada di laparatomi.Meskipun banyak penelitian telah melaporkan komplikasi seperti cedera viseral dan pembuluh darah, beberapa risiko yang tidak diinginkan seperti konversi ke laparotomi selama histerektomi laparoskopi. Tindakan laparoskopi histerektomi meningkat dari 3,9\% pada tahun 1997 menjadi 8,5\% pada tahun 2006. Usia pasien yang lebih muda, kulit putih, komorbiditas rendah, status sosioekonomi yang lebih tinggi, stadium tumor yang lebih rendah, dan penduduk di perkotaan berkaitan dengan penggunaan laparoskopi $(\mathrm{P}<.05)$. Karakteristik dokter berhubungan dengan keterampilan dalam melakukan laparoskopi termasuk latihan yang ditempuh di AS, spesialisasi di bidang ginekologi onkologi, dan pengalaman praktek. Ada tiga jenis histerektomi laparoskopi yang sering dilakukan yaitu Laparoscopy Assisted Vaginal Hysterectomy(LAVH), Total laparoscopic Hysterectomy (TLH), dan Laparoscopically Assisted supracervical Hysterectomy (LASH) ${ }^{3,7,13}$

Pendekatan laparoskopi memiliki keuntungan dibandingkan laparatomi, yaitu kemungkinan pemeriksaan abdomen secara menyeluruh untuk menilai rongga abdomen untuk penyebaran extra-uterin dan cairan peritoneal untuk sitologi. Selain itu, karena pasien tidak memiliki luka operasi yang besar, hasil pendekatan laparoskopi di rumah sakit memiliki masa rawat inap yang lebih singkat, morbiditas luka abdomen yang lebih kecil, pendekatan laparoskopi menyebabkan pasien lebih cepat kembali dalam aktivitas seharihari.Namun demikian, untuk beberapa alasan laparoskopi belum menjadi prosedur yang ditetapkan untuk semua indikasi untuk histerektomi. RSPAD gatot Soebroto merupakan RS rujukan tertinggi di jajaran Angkatan Darat untuk tindakan pada kasus mioma uteri dilakukan dengan 2 cara yaitu laparaskopi dan laparatomi. Pada penelitian ini akan meneliti perbandingan laparoskopi dan laparatomi pada kasus mioma uteri berdasarkan lama operasi, jumlah perdarahan saat operasi, cedera usus/uretra, lama dirawat (Length of Stay) dan transfusi pasca operasi.

\section{METODE}

Desain Penelitian ini menggunakan Cross sectional, dimana exposure dan outcome dinilai dalam waktu bersamaan. Tiap subjek penelitian hanya diobservasi sekali saja dan pengukuran dilakukan terhadap status karakter atau variabel subjek pada saat pemeriksaan. Hal ini tidak 
berarti semua subjek penelitian diamati pada waktu yang sama. Tujuan penelitian ini untuk mengamati penggunaan clinical pathway terhadap tindakan laparaskopi dan laparatomi atasindikasi mioma uteri berdasarkan variabel lama operasi, jumlah perdarahan saat operasi, komplikasi, lama dirawat (Length Of Stay) dan transfusi pasca operasi.Waktu penelitian dilaksanakan pada bulan Januari sampai Juni2017.Populasi pada penelitian ini adalah seluruh wanita dengan diagnosa mioma uteri yang menjalani operasi baik laparatomi maupun laparoskopi di RSPAD Gatot Soebroto.

Populasi sampai dengan bulan Juni pada tahun 2017 sebanyak 53 pasien.Sampel yang diambil adalah seluruh wanita yang terkena mioma uteri (53 responden).Kriteria inklusi pada penelitian ini adalah semua wanita dengan mioma uteri yang menjalani tindakan laparatomi atau laparaskopi di RSPAD Gatot Soebroto, dalam kondisi sadar dan dapat berkomunikasi dengan baik serta bersedia untuk mengisi kuesioner.Adapun kriteria ekslusi pada penelitian ini adalah wanita yang pada saat pengambilan data tidak dapat berpartisipasi dikarena sedang dalam kondisi yang tidak sehat.Variabel dependent pada penelitian ini adalah clinical pathway tindakan laparatomi danlaparaskopi, sedangkan yang menjadi variabel independent adalah lama operasi, jumlah perdarahan, komplikasi, lama dirawat dan trasnfusi pasca operasi. Data dikumpulkan melalui catatan medis pasien lalu diolah dengan menggunakan program Excel dan selanjutnya akan diolah menggunakan program SPSS. Data disajikan dalam bentuk tabel :

Tabel 1

Distribusi Frekuensi Penggunaan Clinical Pathway Terhadap Kesesuaian Diagnosis Pre Op Dan Pasca Op Pada Kasus Mioma Uteri Di RSPAD Gatot Soebroto Bulan Januari - Juni Tahun 2017

\begin{tabular}{lcccccccccc}
\hline $\begin{array}{l}\text { Kesesuaian } \\
\text { Diagnosa }\end{array}$ & \multicolumn{2}{c}{$\begin{array}{c}\text { Laparoskopi } \\
\text { mimektomi }\end{array}$} & \multicolumn{2}{c}{$\begin{array}{c}\text { Laparokopi } \\
\text { histerektomi }\end{array}$} & \multicolumn{2}{c}{$\begin{array}{c}\text { Laparatomi } \\
\text { miomektomi }\end{array}$} & $\begin{array}{c}\text { Laparatomi } \\
\text { histerektomi }\end{array}$ & Total \\
\hline & $\mathbf{n}$ & $\%$ & $\mathbf{n}$ & $\boldsymbol{\%}$ & $\mathbf{n}$ & $\boldsymbol{\%}$ & $\mathbf{n}$ & $\mathbf{\%}$ & $\mathbf{n}$ & $\mathbf{\%}$ \\
\hline Tidak sesuai & 3 & 15 & 2 & 40 & 4 & 26.7 & 9 & 25 & 12 & 22.6 \\
Sesuai & 17 & 85 & 3 & 60 & 11 & 73.3 & 9 & 75 & 41 & 77.4 \\
\hline Total & 20 & 100 & 5 & 100 & 15 & 100 & 18 & 100 & 53 & 100 \\
\hline
\end{tabular}

Sumber : Data Rekam Medis

Berdasarkan tabel 1 dapat diketahui bahwa penggunaan clinical pathway terhadap kesesuaian diagnosis pre operasi dan pasca operasi ditemukan dari 53 kasus mioma uteri ditemukan kasus $(22.6 \%)$ tidak sesuai dan 41 kasus (77.4\%) yang sesuai.

Tabel 2

Distribusi Frekuensi Clinical Pathway Terhadap Operasi Laparoskopi

Dan Laparatomi Berdasarkan Lama Operasi, Jumlah Perdarahan, Komplikasi, LOS

Dan Transfusi Pasca Operasi Di RSPAD Gatot Soebroto

Bulan Januari - Juni Tahun 2017

\begin{tabular}{lrrrrr}
\hline Kategori & $\begin{array}{c}\text { Lama } \\
\text { operasi } \\
\text { (menit) }\end{array}$ & $\begin{array}{c}\text { Jumlah } \\
\text { perdarahan }\end{array}$ & $\begin{array}{c}\text { Kompli } \\
\text { kasi }\end{array}$ & $\begin{array}{c}\text { Transfusi } \\
\text { pasca } \\
\text { operasi }\end{array}$ & LOS \\
\hline Mean & 150,09 & 393,02 & & 165,81 & 4,28 \\
Median & 120 & 150 & 0 & 4 \\
Mode & 240 & 100 & 0 & 5 \\
Std. Deviation & 86,3 & 653,407 & 424,595 & 1,133 \\
Variance & 7447,664 & 426940,711 & & 180280,77 & 1,284 \\
\hline
\end{tabular}




\begin{tabular}{|c|c|c|c|c|c|c|}
\hline \multicolumn{2}{|l|}{ Skewness } & 1,247 & 3,887 & & 3,091 & 0,483 \\
\hline \multicolumn{2}{|l|}{$\begin{array}{l}\text { Std. Error of } \\
\text { Skewness }\end{array}$} & 0,327 & 0,327 & & 0,327 & 0,327 \\
\hline \multicolumn{2}{|l|}{ Kurtosis } & 1,246 & 18,177 & & 9,635 & 0,104 \\
\hline \multicolumn{2}{|l|}{$\begin{array}{l}\text { Std. Error of } \\
\text { Kurtosis }\end{array}$} & 0,644 & 0,644 & & 0,644 & 0,644 \\
\hline \multicolumn{2}{|l|}{ Range } & 375 & 3990 & & 2095 & 5 \\
\hline \multicolumn{2}{|l|}{ Minimum } & 45 & 10 & 0 & 0 & 2 \\
\hline \multicolumn{2}{|l|}{ Maximum } & 420 & 4000 & 1 & 2095 & 7 \\
\hline \multicolumn{2}{|l|}{ Sum } & 7955 & 20830 & & 8788 & 227 \\
\hline \multirow{3}{*}{ Percentiles } & 25 & 85 & 100 & & 0 & 3 \\
\hline & 50 & 120 & 150 & & 0 & 4 \\
\hline & 75 & 210 & 375 & & 0 & 5 \\
\hline
\end{tabular}

Dari tabel 2 dapat diketahui distribusi penggunaan clinical pathway terhadap operasi laparoskopi dan laparatomi di RSPAD Gatot Soebroto bulan Januari-Juni 2017. Rata-rata lama berlangsung selama 150.09 menit, sementara itu bila dilihat dari variabel jumlah perdarahan rata-rata selama operasi laparakopi dan laparatomi terjadi perdarahan 393.02 cc,lama perawatan rata-rata 4 hari, transfusi pasca operasi tidak selalu diberikan kepada pasien.

Table 3

Hubungan Penggunaan Clinical Pathway Terhadap Tindakan Laparaskopi Dan Laparatomi Dengan Lama Operasi Di Lantai 2 Ginekologi

RSPAD Gatot Soebroto

\begin{tabular}{|c|c|c|c|c|c|c|}
\hline \multirow[b]{2}{*}{$\begin{array}{l}\text { Lama } \\
\text { Operasi }\end{array}$} & \multicolumn{4}{|c|}{ Tindakan Operasi } & \multirow[b]{2}{*}{ Total } & \multirow[b]{2}{*}{$\begin{array}{c}\mathbf{P} \\
\text { Value }\end{array}$} \\
\hline & $\begin{array}{l}\text { Laparoskopi } \\
\text { miomektomi }\end{array}$ & $\begin{array}{l}\text { Laparoskopi } \\
\text { histerektomi }\end{array}$ & $\begin{array}{l}\text { Laparatomi } \\
\text { miomektomi }\end{array}$ & $\begin{array}{l}\text { Laparatomi } \\
\text { histerektomi }\end{array}$ & & \\
\hline & n & $\%$ & $\mathbf{n}$ & $\%$ & $\mathbf{n}$ & \\
\hline \multirow[t]{2}{*}{$\leq 3 \mathrm{jam}$} & 10 & 2 & 13 & 10 & 35 & 0.675 \\
\hline & $28,60 \%$ & $5,70 \%$ & $37,10 \%$ & $28,60 \%$ & $100 \%$ & \\
\hline \multirow[t]{3}{*}{$>3$ jam } & 11 & 4 & 1 & 2 & 18 & \\
\hline & $61,10 \%$ & $22,20 \%$ & $5,60 \%$ & $11,10 \%$ & $100 \%$ & \\
\hline & 21 & 6 & 14 & 12 & 53 & \\
\hline Total & $39,60 \%$ & $11,30 \%$ & $26,40 \%$ & $22,60 \%$ & $100 \%$ & \\
\hline
\end{tabular}

Sumber : Data Rekam Medis RSPAD

Dari tabel 3 dapat diketahui bahwa hasil analisa hubungan penggunaan clinical pathway terhadap tindakan laparoskopi laparatomi dengan lama operasi diperoleh bahwa ada sebanyak 35 pasien yang dilakukan operasi kurang dari 3 jam dan sebanyak 18 pasien yang dilakukan operasi lebih dari 3 jam.
Hasil uji statistik diperoleh nilai $\mathrm{p}=0.675$ maka dapat disimpulkan tidak ada perbedaan proporsi antara penggunaan clinical pathway tindakan laparaskopi dengan laparatomi terhadaplama operasi (tidak ada hubungan yang signifikan antara tindakan laparaskopi dengan laparatomi terhadap lama operasi). 


\section{Table 4}

Hubungan Penggunaan Clinical Pathway terhadap tindakan Laparaskopi dan laparatomi dengan jumlah perdarahandi Lantai 2 Ginekologi

RSPAD Gatot Soebroto

\begin{tabular}{|c|c|c|c|c|c|c|}
\hline \multirow{3}{*}{$\begin{array}{c}\text { Jumlah } \\
\text { perdarahan }\end{array}$} & \multicolumn{4}{|c|}{ Tindakan Operasi } & \multirow{2}{*}{ Total } & \multirow{3}{*}{$\begin{array}{c}\mathbf{P} \\
\text { Value }\end{array}$} \\
\hline & $\begin{array}{l}\text { Laparoskopi } \\
\text { miomektomi }\end{array}$ & $\begin{array}{l}\text { Laparoskopi } \\
\text { histerektomi }\end{array}$ & $\begin{array}{l}\text { Laparatomi } \\
\text { miomektomi }\end{array}$ & $\begin{array}{l}\text { laparatomi } \\
\text { histerektomi }\end{array}$ & & \\
\hline & $\mathbf{n}$ & $\%$ & n & $\%$ & $\mathbf{n}$ & \\
\hline \multirow[t]{2}{*}{$\leq 300 \mathrm{cc}$} & 18 & 5 & 7 & 7 & 37 & 0.036 \\
\hline & $48,60 \%$ & $13,50 \%$ & $18,90 \%$ & $18,90 \%$ & $100 \%$ & \\
\hline \multirow[t]{3}{*}{$>300 \mathrm{cc}$} & 3 & 1 & 7 & 16 & 18 & \\
\hline & $18,80 \%$ & $6,30 \%$ & $43,80 \%$ & $31,30 \%$ & $100 \%$ & \\
\hline & 21 & 6 & 14 & 12 & 53 & \\
\hline total & $39,60 \%$ & $11,30 \%$ & $26,40 \%$ & $22,60 \%$ & $100 \%$ & \\
\hline
\end{tabular}

. Sumber : Data Rekam Medis RSPAD

Pada tabel 4 Hasil analisa hubungan penggunaan clinical pathway terhadap tindakan laparoskopi laparatomi dengan terhadap jumlah perdarahan diperoleh bahwa ada sebanyak 18 pasien yang dilakukan laparoskopi miomektomi dengan jumlah perdarahan $\leq 300$ cc. Dan ada 3 pasien yang diilakukan operasi laparoskopi miomektomi dengan jumlah perdarahan > 300cc. Sedangkan pada pasien yang dilakukan laparatomi miomektomi ada 7 pasien dengan jumlah perdarahan $\leq 300 \mathrm{cc}$ dan 7 pasien dengan laparatomi miomektomi jumlah perdarahan $>300 \mathrm{cc}$. Hasil uji statistik diperoleh nilai $\mathrm{p}=0.036$ maka dapat disimpulkan tidak ada perbedaan proporsi penggunaan clinical pathway antara tindakan laparaskopi dengan laparatomi terhadap jumlah perdarahan (tidak ada hubungan yang signifikan antara tindakan laparaskopi dengan laparatomi terhadap jumlah perdarahan).

Table 5

Hubungan Tindakan Laparaskopi Dan Laparatomi Dengan Komplikasi

Di Lantai 2 Ginekologi RSPAD Gatot Soebroto

\begin{tabular}{|c|c|c|c|c|c|c|}
\hline \multirow{3}{*}{ Komplikasi } & \multicolumn{4}{|c|}{ Tindakan Operasi } & \multirow[b]{2}{*}{ Total } & \multirow{3}{*}{$\begin{array}{c}\mathbf{P} \\
\text { Value }\end{array}$} \\
\hline & $\begin{array}{l}\text { Laparoskopi } \\
\text { miomektomi }\end{array}$ & $\begin{array}{l}\text { Laparoskopi } \\
\text { histerektomi }\end{array}$ & $\begin{array}{l}\text { Laparatomi } \\
\text { miomektomi }\end{array}$ & $\begin{array}{l}\text { Laparatomi } \\
\text { histerektomi }\end{array}$ & & \\
\hline & $\mathbf{n}$ & $\%$ & $\mathbf{n}$ & $\%$ & $\mathbf{n}$ & \\
\hline \multirow[t]{2}{*}{ Ada } & 0 & 1 & 1 & 0 & 2 & 0,214 \\
\hline & $48,60 \%$ & $13,50 \%$ & $18,90 \%$ & $18,90 \%$ & $100 \%$ & \\
\hline \multirow[t]{2}{*}{ Tidak ada } & 21 & 5 & 13 & 12 & 51 & \\
\hline & $41,20 \%$ & $9,80 \%$ & $25,50 \%$ & $23,50 \%$ & $100 \%$ & \\
\hline \multirow[t]{2}{*}{ Total } & 21 & 6 & 14 & 12 & 53 & \\
\hline & $39,60 \%$ & $11,30 \%$ & $26,40 \%$ & $22,60 \%$ & $100 \%$ & \\
\hline
\end{tabular}

Sumber : Data Rekam Medis RSPAD

Dari tabel 5 dapat diketahui Hasil analisa penggunaan clinical pathway terhadap tindakan laparoskopi laparatomi dengan terhadap komplikasi, diperoleh bahwa tidak ada pasien yang dilakukan laparoskopi miomektomi dengan komplikasi. Sementara itu pada tindakan laparoskopi histerektomi dan laparatomi miomektomi masing-masing ditemukan 1 pasien disertai komplikasi. Hasil uji statistik diperoleh nilai $\mathrm{p}=0.094$ maka dapat 
disimpulkan tidak ada perbedaan proporsi antara tindakan laparaskopi dengan laparatomi terhadap jumlah perdarahan (tidak ada hubungan yang signifikan antara tindakan laparaskopi dengan laparatomi terhadap jumlah perdarahan).

\section{Table 6}

Hubungan Tindakan Laparaskopi Dan Laparatomi Dengan Length Of Stay

Di Lantai 2 Ginekologi RSPAD Gatot Soebroto

\begin{tabular}{|c|c|c|c|c|c|c|}
\hline \multirow{3}{*}{$\begin{array}{l}\text { Length } \\
\text { of stay }\end{array}$} & \multicolumn{4}{|c|}{ Tindakan Operasi } & \multirow[b]{2}{*}{ Total } & \multirow{3}{*}{$\underset{\text { Value }}{\mathbf{P}}$} \\
\hline & $\begin{array}{l}\text { Laparoskopi } \\
\text { miomektomi }\end{array}$ & $\begin{array}{l}\text { Laparoskopi } \\
\text { histerektomi }\end{array}$ & $\begin{array}{l}\text { Laparatomi } \\
\text { miomektomi }\end{array}$ & $\begin{array}{l}\text { Laparatomi } \\
\text { histerektomi }\end{array}$ & & \\
\hline & $\mathbf{n}$ & $\%$ & $\mathbf{n}$ & $\%$ & $\mathbf{n}$ & \\
\hline \multirow[t]{2}{*}{$\leq 3$ hari } & 7 & 2 & 4 & 0 & 13 & 0.589 \\
\hline & $53,80 \%$ & $15,40 \%$ & $30,80 \%$ & $0,00 \%$ & $100 \%$ & \\
\hline \multirow[t]{2}{*}{$>3$ hari } & 14 & 4 & 10 & 12 & 40 & \\
\hline & $35,00 \%$ & $10,00 \%$ & $25,00 \%$ & $30,00 \%$ & $100 \%$ & \\
\hline \multirow[t]{2}{*}{ Total } & 21 & 6 & 14 & 12 & 53 & \\
\hline & $39,60 \%$ & $11,30 \%$ & $26,40 \%$ & $22,60 \%$ & $100 \%$ & \\
\hline
\end{tabular}

Sumber : Data Rekam Medis RSPAD

Dari tabel 6 dapat diketahui Hasil analisa hubungan penggunaan clinical pathway terhadap tindakan laparoskopi laparatomi terhadap dengan Lenght of Stay diperoleh bahwa ada sebanyak 13 pasien yang dilakukan laparoskopi dengan lama perawatan $\leq 3$ hari. Dan ada 40 pasien yang dilakukan operasi laparoskopi dengan lama perawatan $>3$ hari.
Hasil uji statistik diperoleh nilai $\mathrm{p}=0.589$ maka dapat disimpulkan tidak ada perbedaan proporsi antara tindakan laparaskopi/laparatomi dengan Length of Stay (tidak ada hubungan yang signifikan antara tindakan laparaskopi/laparatomi dengan lenght of stay.

Table 7

Hubungan Tindakan Laparaskopi Dan Laparatomi Dengan Transfusi Pasca Operasi Di Lantai 2 Ginekologi RSPAD Gatot Soebroto

\begin{tabular}{|c|c|c|c|c|c|c|}
\hline \multirow{3}{*}{$\begin{array}{c}\text { Transfusi } \\
\text { pasca } \\
\text { operasi }\end{array}$} & \multicolumn{4}{|c|}{ Tindakan Operasi } & \multirow[b]{2}{*}{ Total } & \multirow{3}{*}{$\begin{array}{c}\mathbf{P} \\
\text { Value }\end{array}$} \\
\hline & $\begin{array}{l}\text { Laparoskopi } \\
\text { miomektomi }\end{array}$ & $\begin{array}{l}\text { Laparoskopi } \\
\text { histerektomi }\end{array}$ & $\begin{array}{l}\text { Laparatomi } \\
\text { miomektomi }\end{array}$ & $\begin{array}{l}\text { Laparatomi } \\
\text { histerektomi }\end{array}$ & & \\
\hline & $\mathbf{n}$ & $\%$ & $\mathbf{n}$ & $\%$ & $\mathbf{n}$ & \\
\hline \multirow[t]{2}{*}{$\begin{array}{l}\text { tidak } \\
\text { transfusi }\end{array}$} & 17 & 5 & 9 & 10 & 41 & 0.510 \\
\hline & $41,50 \%$ & $12,20 \%$ & $22,00 \%$ & $24,40 \%$ & $100 \%$ & \\
\hline \multirow[t]{2}{*}{$\begin{array}{l}\text { transfusi } \\
\text { pasca } \\
\text { operasi }\end{array}$} & 4 & 1 & 5 & 2 & 12 & \\
\hline & $33,30 \%$ & $8,30 \%$ & $41,70 \%$ & $16,70 \%$ & $100 \%$ & \\
\hline \multirow[t]{2}{*}{ Total } & 21 & 6 & 14 & 12 & 53 & \\
\hline & $39,60 \%$ & $11,30 \%$ & $26,40 \%$ & $22,60 \%$ & $100 \%$ & \\
\hline
\end{tabular}

Sumber : Data Rekam Medis RSPAD

Dari tabel 5.7 dapat diketahui Hasil analisa penggunaan clinical pathway terhadap tindakan laparoskopi laparatomi dengan transfusi pasca operasi diperoleh bahwa ada sebanyak 22 
pasien yang dilakukan laparoskopi dengan tidak memerlukan transfusi. Dan ada 5 pasien yang diilakukan operasi laparoskopi perlu transfusi pasca operasi. Sedangkan pada pasien yang dilakukan laparatomi terdapat 19 pasien tidak memerlukan transfusi dan 7 pasien memerlukan transfusi pasca operasi. Hasil uji statistik diperoleh nilai $\mathrm{p}=0.510$ maka dapat disimpulkan tidak ada perbedaan proporsi antara tindakan laparaskopi/laparatomi dengan transfusi pasca operasi (tidak ada hubungan yang signifikan antara tindakan laparaskopi/laparatomi dengan transfusi pasca operasi.

\section{DISKUSI}

\section{Penggunaan clinical pathway terhadap kesesuaian diagnosa pre operasi dan pasca operasi laparaskopi dan laparatomi kasus mioma uteri.}

Dari hasil penelitian ini diperoleh penggunaan clinical pathway terhadap kesesuaian diagnosa pre operasi dan pasca operasi pada tindakan laparoskopi dan laparatomi ditemukan dari 53 kasus mioma uteri terdapat 12 kasus (22.6\%) tidak sesuai dan 41 kasus (77.4\%) yang sesuai. Clinical pathway dibuat sebagai alur yang menunjukkan secara detail tahap-tahap pelayanan kesehatan termasuk hasil yang diharapkan. Clinical pathway menggambarkan proses mulai saat penerimaan pasien sampai pemulangan pasien. Ada yang bilang bahwa proses perawatan pasien adalah proses yang sarat seni bernilai tinggi. Terkadang dokter memberikan pelayanan yang bervariasi sesuai denga ilmu pengetahuan dan "rasa" yang dimilikinya. Ada kalanya, variasi ini memang diperlukan, mengingat masing-masing pasien juga memiliki variasi kondisi tubuh saat bereaksi terhadap obat dan penyakit yang dideritanya. Namun tidak jarang, variasi yang diberikan malah tidak perlu dan bahkan beresiko membebani pasien. Beban yang paling "mudah" dirasakan adalah beban biaya. Agar kondisi seperti ini bisa dikendalikan, implementasi clinical pathway dapat menjadi pilihan untuk dilakukan. ${ }^{2}$

\section{Hubungan Penggunaan Clinical Pathway Tindakan Laparoskopi Dengan Laparatomi Terhadap Lama Operasi}

Dari hasil penelitian yang dilakukan di RSPAD diperoleh ada 12 pasien yang dilakukan operasi laparoskopi dengan waktu $\leq$ 3 jam dan ditemukan 15 pasien yang menjalani operasi laparoskopi lebih dari 3 jam. Sementara itu untuk pasien yang dilakukan laparatomi ada 23 pasien yang menjalani operasi $\leq 3$ jam dan ada 3 pasien yang menjalani laparatomi lebih dari 3 jam. Hasil uji statistik nilai $\mathrm{p}=0.675$ (Pearson Chi Square) maka dapat disimpulkan tidak ada perbedaan proporsi antara tindakan laparaskopi dengan laparatomi terhadap lama operasi (tidak ada hubungan yang signifikan antara tindakan laparaskopi dengan laparatomi terhadap lama operasi). Lama operasi laparoskopi miomektomi berlangsung paling cepat 60 menit dan paling lama 420 menit. Sementara itu operasi laparatomi miomektomi berlangsung paling cepat 45 menit dan paling lama 240 menit. Untuk meakukan laparoskopi miomektomi diperlukan syarat dengan keterampilan operator menjadi syarat utama. Syarat lainnya adalah tersedianya instrumen tambahan seperti needle holder, myoma screw, morselator dan benang vicryl bermacam ukuran dengan jarum atraumatik. ${ }^{13}$ Konsensuspara ahli menyatakan ukuran maksimal mioma yang layak dilakukan laaroskopi operatif adalah 8-10 $\mathrm{cm}$ dan jumlah miom yang besar tidak lebih dari 4 buah. Untuk mioma intramural atau subserosum tunggal ukurannya tidak melebihi $15 \mathrm{~cm} .^{11}$

Sushan (1999) melakukan sebuah penelitian untuk menilai lama operasi laparoskopi ginekologis. Sushan menganalisis secara retrospektif 1000 operasi laparoskopi berturut-turut berdasarkan prosedur. Diagnostik laparoskopi dansterilisasi laparoskopi secara khusus dikecualikan dari analisis. Berbagai prosedur laparoskopi dikelompokkan dan dianalisis dengan enam kategori utama. Lama operasi rata-rata untuk semua kasus adalah 76,9 menit (kisaran 10400). Dalam 38 kasus $(3,8 \%)$ prosedur laparoskopi diubah menjadi laparotomi. Waktu operasi rata-rata untuk mengobati kehamilan ektopik dan penyakit tuba kira-kira 60 menit (kisaran 13-240). Pembedahan untuk endometriosis dan kista ovarium rata-rata 72 menit (kisaran 10-240). Miektomi dan histerektomi laparoskopi rata-rata 113 dan 131 menit masing-masing (kisaran 25-400). Hasil penelitiannya menunjukkan bahwa sementara lama operasi untuk laparoskopi operatif kurang dari 75 menit, rentang waktu operasi sangat 
bagus. antara tindakan laparaskopi/laparatomi dengan lama operasi (tidak ada hubungan yang signifikan antara tindakan laparaskopi/laparatomi dengan lama operasi). Dari hasil analisis diperoleh nilai $\mathrm{OR}=0.431$, artinya lama operasi $\leq 2$ jam mempunyai peluang 0.431 kali untuk tindakan laparoskopi dibandingkan dengan lama operasi $>2$ jam. ${ }^{5}$

Stringer dkk (1997) membandingkan 49 miomektomi laparoskopi dengan 49 operasi terbuka untuk miomektomi. laparoskopi membutuhkan lebih banyak waktu dengan 258 menit banding 133 menit untuk laparotomi. Durasi tergantung pada ukuran, jumlah, kedalaman dan pengalaman ahli bedah. Oleh karena itu USG pra operasi dan evaluasi histeroskopi adalah suatu keharusan untuk memutuskan rute. Ahli bedah juga harus mempertimbangkan pengalamannya sendiri untuk menentukan dan memulai dengan fibroid sub serosa posterior berukuran menengah ${ }^{7}$

Bulletti dkk melakukan perbandingan acak antara myomectomy laparoskopi dan operasi perut dari tahun 1993 sampai 1998. Dengan total 131 pasien-65 laparotomi dan 66 laparoskopi. Semua memiliki setidaknya satu fibroid besar $>5 \mathrm{~cm}$. Sejumlah perbedaan yang signifikan ditemukan di antara keduanya. tentang jumlah, ukuran dan lokasi mioma yang besar. Waktu operasi sedikit tapi tidak secara signifikan lebih rendah pada operasi terbuka. Tiga kali melakukan pembedahan $(4,3 \%)$ karena hemostasis dan penjahitan yang sulit terjadi ${ }^{8}$. Namun penelitian menunjukkan, rentang waktu operasi untuk miomektomi laparoskopi bervariasi dan tidak dapat diprediksi. Stadium teater tetap untuk miomektomi laparoskopi tidak mungkin dilakukan.

\section{Hubungan Penggunaan Clinical Pathway Tindakan Laparoskopi Dengan Laparatomi Terhadapjumlah perdarahan.}

Dari hasil penelitian yang dilakukan dari 26 tindakan laparoskopi dan 27 laparotomi ditemukan jumlah minimal perdarahan pada laparoskopi $50 \mathrm{cc}$ dan maksimal $1600 \mathrm{cc}$, sementara pada laparatomi minimal $50 \mathrm{cc}$ dan maksimal 4000cc. Hasil uji statistik diperoleh nilai $\mathrm{p}=0.036$ maka dapat disimpulkan ada perbedaan proporsi penggunaan clinical pathway antara tindakan laparaskopi dengan laparatomi terhadap jumlah perdarahan (ada hubungan yang signifikan antara tindakan laparaskopi dengan laparatomi terhadap jumlah perdarahan).

Briones (2010) melakukan penelitian perbandingan laparoskopi dan laparatomi. Dari penelitian diperoleh hasil seperti berikut ini : Kelompok 1 (pendekatan laparoskopi) terdiri dari 102 pasien $(60,3 \%)$, dan kelompok 2 (pendekatan laparotomi) memiliki 67 pasien (39,7\%). Jumlah perdarahan : 55,7 +/- 21,4 mL vs $91,6+/-29,2 \mathrm{~mL}$ (p <0,0001. Bedah laparoskopi berbeda dengan bedah konvensional karena laparoskopi hanya membutuhkan akses minimal ke tubuh pasien. Pada bedah konvensional, sayatan di perut bisa sepanjang belasan sentimeter. Sementara, pada bedah laparoskopi, akses yang dibutuhkan hanya 2 milimeter sampai 10 milimeter.Dengan bedah laparoskopi, paling-paling hanya dibutuhkan empat hingga lima lubang kecil untuk memasukkan alat. Lantaran akses yang dibutuhkan kecil, tindakan penjahitan kadang tak dibutuhkan lagi. Lubang kecil yang dihasilkan cukup ditutup dengan plester pembalut (band aid) khusus. Setelah luka tersebut kering pun, tak akan ada bekas luka parut memanjang yang kadang menakutkan.

Kelompok studi manapun. ${ }^{6}$

\section{Hubungan Penggunaan Clinical Pathway Tindakan Laparoskopi Dengan Laparatomi Terhadapkomplikasi}

Dari hasil penelitian yang dilakukan dari 26 tindakan laparoskopi dan 27 laparotomi ditemukan masing-masing 1 komplikasi. Hasil uji statistik diperoleh nilai $\mathrm{p}=0.214$ maka dapat disimpulkan tidak ada perbedaan proporsi penggunaan clinical pathway antara tindakan laparaskopi dengan laparatomi terhadap jumlah perdarahan (tidak ada hubungan yang signifikan antara tindakan laparaskopi dengan laparatomi terhadap jumlah perdarahan).

L.Mettler dkk melakukan analisis retrospektif terhadap 178 pasien yang menjalani miomektomi laparoskopi di rumah sakit universitas, kampus Keil, Jerman pada tahun 2000 sampai 2003. Waktu operasi ratarata adalah 90 menit dan rata-rata tinggal di rumah sakit adalah $2+\ldots 0,5$ hari. 2 pasien memiliki hematoma kecil di dinding perut. Tidak ada komplikasi terlambat ditemukan.7 kasus memerlukan tingkat myomectomy laparoskopi kedua. Kehamilan lebih dari 55\% dicapai pada kasus infertilitas. Pemulihan operasi dan kembalinya ke kehidupan normal 
lebih cepat daripada dibandingkan dengan laparotomi. dia menyimpulkan bahwa myomectomy laparoskopi menjadi teknik pilihan untuk fibroid bawaan-subserosal dan intramural pada pasien yang dipilih dengan benar. ${ }^{10}$. Dibandingkan dengan pendekatan laparotomi laparoskopi miomektomi memiliki kelebihan seperti nyeri minimal, penyembuhan cepat, perdarahan minimal, angka morbiditas dan komplikasi rendah, serta kejadian adhesi yang rendah. ${ }^{11}$

\section{Hubungan Penggunaan Clinical} Pathway Tindakan Laparoskopi Dengan Laparatomi Terhadap lama perawatan llenght of stay

Dari hasil penelitian yang dilakukan dari 26 tindakan laparoskopi dan 27 laparotomi ditemukan minimal lama perawatan/lenght of staypada laparoskopi 2 hari dan maksimal 7 hari, sementara pada laparatomi minimal 3 hari dan maksimal 7 hari. Hasil uji statistik diperoleh nilai $\mathrm{p}=0.589$ maka dapat disimpulkan tidak ada perbedaan proporsi penggunaan clinical pathway antara tindakan laparaskopi dengan laparatomi terhadaplama perawatan (tidak ada hubungan yang signifikan antara tindakan laparaskopi dengan laparatomi terhadaplama perawatan).Hasil observasi lain yang ditemukan di lapangan adalah setelah dilakukan operasi pasien tidak mau melakukan mobilisasi dini padahal ini penting sekali dilakukan. Pasien merasa takut akan luka operasi dan nyeri pasca operasi. Latihan ambulasi dini dapat meningkatkan sirkulasi darah yang akan memicu penurunan nyeri dan penyembuhan luka lebih cepat. Terapi latihan dan mobilisasi merupakan modalitas yang tepat untuk memulihkan fungsi tubuh bukan saja pada bagian yang mengalami cedera tetapi juga pada keseluruhan anggota tubuh. Terapi latihan dapat berupa latihan pasif dan aktif, terapi latihan juga dapat berupa miring kanan kiri, duduk dan berjalan sedini mungkin untuk meningkatkan kemampuan aktivitas mandiri.

Penelitian yang dilakukan oleh Briones (2010) meneliti perbandingan laparotomi dan laparoskopi pada mioma uteri diperoleh hasil untuk lama perawatan atau length of stay 1,6 $+/-0,57$ vs $2,7+/-0,42$ hari $\left(\mathrm{p}<0,0001 .{ }^{6}\right.$

\footnotetext{
Hubungan Penggunaan Clinical Pathway Tindakan Laparoskopi Dengan Laparatomi Terhadap transfusi pasca operasi
}

Dari hasil penelitian yang dilakukan dari 26 tindakan laparoskopi dan 27 laparotomi ditemukan minimal transfusi pasca operasi pada laparoskopi $182 \mathrm{cc}$ dan maksimal $1235 \mathrm{cc}$, sementara pada laparatomi minimal $171 \mathrm{cc}$ dan maksimal 2095 cc. Hasil uji statistik diperoleh nilai $\mathrm{p}=0.510$ maka dapat disimpulkan tidak ada perbedaan proporsi penggunaan clinical pathway antara tindakan laparaskopi dengan laparatomi terhadap transfusi pasca operasi (tidak ada hubungan yang signifikan antara tindakan laparaskopi dengan laparatomi terhadap transfusi pasca operasi).

Tindakan miomektomi mempunyai resiko kehilangan banyak darah disebabkan oleh banyaknya jumlah pembuluh darah yang terdapat pada leiomioma tersebut. Jumlah volume kehilangan darah saat miomektomi melalui laparatomi yaitu sebanyak $200 \mathrm{~mL}$ sampai dengan $800 \mathrm{~mL}$ Perdarahan saat operasi dapat menyebabkan anemia, hipovolemik dan abnormalitas koagulasi. Sehingga memerlukan suatu cara untuk menurunkan jumlah kehilangan darah tersebut saat dilakukan miomektomi dengan tujuan menurunkan kebutuhan untuk tindakan transfusi darah. Injeksi vasopressin umumnya digunakan pada proses miomektomi untuk mengurangi jumlah kehilangan darah. Selain itu pengikatan rahim menggunakan tourniquet juga menjadi metode yang umum digunakan untuk mengurangi jumlah kehilangan darah. ${ }^{12}$

\section{KESIMPULAN}

Dari hasil penelitian ini diperoleh 53 kasus mioma uteri, terdapat 21 pasien (39.6\%) dilakukan tindakan laparoskopi miomektomi, 6 pasien (11.3\%) dilakukan laparoskopi histerektomi, 14 pasien (26.4\%) dilakukan laparatomi miomektomi dan 12 pasien (22.6\%) dilakukan laparatomi histerektomi. Penggunaan clinical pathway terhadap kesesuaian diagnosa pre operasi dan pasca operasi pada tindakan laparoskopi dan laparatomi ditemukan dari 53 kasus mioma uteri terdapat 12 kasus (22.6\%) tidak sesuai dan 41 kasus (77.4\%) yang sesuai. Dari 5 variabel yang diambi (lama operasi, jumlah perdarahan, lenght of stay, komplikasi dan transfusi) hanya ada 1 variabel yang berhubungan dengan penggunaan clinical pathway terhadap tindakan laparatomi dan laparaskopi pada kasus mioma uteri yaitu jumlah perdarahan $(\mathrm{p}=0.036)$. 


\section{SARAN}

Saat ini di RSPAD Gatot Soebroto belum semua dokter obggyn dapat melakukan tindakan laparoskopi, masih diperlukan pelatihan. Persetujuan tindakan (informed consent) sebelum operasi dikaji ulang pasien

\section{DAFTAR PUSTAKA}

1. drg. Puti Aulia Rahma, MPH, Implementasi Clinical Pathway Untuk Kendali Mutudan Kendali Biaya Pelayanan Kesehatan, www.mutupelayanankesehatan.net. 2013

2. INA CBGs, Apa itu clinical pathway, inacbg.blogspot.co.id. 2014

3. Parker, Gomel V. Isobaric laparoscopy. Canada J Obstet Gynecol:JOGC. 2007;29(6):493-4

4. Hadibroto, Peran laparoskopi operatif pada nyeri pelvis kronis. Indonesia $\mathbf{J}$ Obstet Gynecol 2006;30(3): 152-5

5. Sushan, How Long Does Laparoscopic Surgery Really Take? Lesson Learned From 1000 Operative Laparoscopies. Pubmed, NCBI, US National Library of Medicine National Institutes of Health. 1999

6. Briones, Comparison of laparoscopic vs. laparotomy treatment in ovarian teratomas, Pubmed, NCBI, US National Library of Medicine National Institutes of Health. www.ncbi.nlm.nih.gov, ginecol obstet Mex 2010 Oct;78(10) 527-32

7. NH Stringer, JC Walker, and PM Meyer Comparison of 49 laparoscopic myomectomies with 49 open myomectomies.J Am Assoc Gynecol Laparosc, Aug 1997; 4[4]: 457-64.

8. R. Seracchioli, S. Rossi, F. Govoni, E. Rossi, S. Venturoli, C. Bulletti, and C. Flamigni Fertility and obstetric outcome harus memahami tentang prosedur yang akan dilakukan dari mulai masuk perawatan sampai pulang perawatan. Pasien diberikan pendidikan kesehatan tentang mobilisasi dini pasca operasi sehingga dapat mengurangi lama perawatan atau lenght of stay di RS. Puasa pre operasi dilakukan tidak terlalu dini sehingga mengurangi gastritis pasien

after laparoscopic myomectomy of large myomata: a randomized comparison with abdominal myomectomy,Hum. Reprod., Dec 2000; 15: 2663 - 2668.

9. A. Holzer, S. T. Jirecek, U. M. Illievich, J. Huber, and R. J. Wenzl, Laparoscopic Versus Open Myomectomy: A DoubleBlind Study to Evaluate Postoperative Pain Anesth. Analg. May 2006; 102: 1480 - 1484.

10. L.Mettler, T. Schollmeyer,W .Jonat, update on laparoscopic myomectomy, Gynecological Surgery, vol.2, number 3 / sept. $2005 ; 173$ - 177 www.springerlink.com/index/M7KHX37 546111J38.pdf

11. Wahyu Hadisaputra, Perkembangan Laparoskopi Operatif di Indonesia, departemen obstetri dan ginekologi Univeritas Indonesia, Vol 2 no 2, April 2014

12. Nadya Lusiana, Fara Vitantri Diah C, Minimize Blood Loss during Myomectomy: Comparative Literature Study of Several Intervention Techniques Department of Obstetric \& Gyneacology, Faculty of Medicine, University of Indonesia, Department of Obstetric \& Gyneacology, Fatmawati General Hospital. 2014

13. Miller CE. Unmet therapeutic needs for uterine myomas. J Minim Invasive Gynecol. 2009;16 (1) : 11 - 21 